\title{
EVALUATION AND ESTIMATION OF CAMELUS DROMEDARIUS STATUS INFESTED WITH MANGE
}

\author{
HASSAN Y.A.H. MAHMOUD ${ }^{1}$; ALSAGHER O. ALI ${ }^{1}$; ADEL ELSYED AHMED ${ }^{2}$ and \\ EBTSAM F. ALI ${ }^{3}$ \\ ${ }^{1}$ Division of Infectious Diseases, Animal Medicine Department, Faculty of Veterinary Medicine, South Valley University, Qena 83523, \\ Egypt. \\ ${ }^{2}$ Division of Clinical Laboratory Diagnosis, Animal Medicine Department, Faculty of Veterinary Medicine, South Valley University, Qena \\ 83523, Egypt \\ ${ }^{3}$ Division of Clinical Laboratory Diagnosis, Directorate of Veterinary Medicine, Aswan, Egypt.
}

Received: 26 October 2015; Accepted: 22 November 2015

\begin{abstract}
One hundred fifty seven samples from one humped camel (Camelus dromedarius) were collected in three different areas (Draw, Gharb Aswan Village and Gharb Sohil Village) in Aswan Governorates from April 2014 to April 2015, eleven camels suffered from blood parasite Trypanosoma evansi, thirty one camels suffered from internal parasites Tricuries Cameli, ninety nine camels suffered from clinical mange infestation, free from internal and blood parasites and sixteen clinically healthy camel. Infected animals with mange were significant decreases in TEC, Hb, Basophil and Monocytes, while significant increases in TLC, Eosinophils, Lymphocytes and Neutrophil. There was a significant increased in Triglyceride and glucose concentrations in infected male than healthy, while it show a significant decreased in infected female than healthy, in addition to Albumin, ALT, HDL and Calcium levels had no significant different between infected and healthy, but AST, LDL and cholesterol levels show a significant increased in infected animals than healthy.
\end{abstract}

Key words: Mange, Camelus dromedairus and Mange

\section{INTRODUCTION}

Camelus dromedarius is a multipurpose and preferable animal in Bedouin regions, it play an important role in national income as a source of meat and hides, in some area are potentially better milkier than tropical cattle breeds, it employed for many functions as a working animal and in transportation, in addition to its use in military and police services in borders and desert province, these animals are also used in racing, sports and serve as a wealth reserve forming the social structure of many Bedouin Tribes (Higgin 1985).

Mange is one of parasite that causing signs of itching, purities, loss of hair, dryness of the skin and restlessness. Lesions were concentrated mainly on trunk, tail, face and lips and frequently involved more than one area (Al-Saad et al., 2000).

Corresponding author: Dr. HASSAN Y.A.H. MAHMOUD E-mail address: hayvet2002@yahoo.com

Present address: Division of Infectious Diseases, Animal Medicine Department, Faculty of Veterinary Medicine, South Valley University, Qena 83523, Egypt.
The percent of mange infection in camel in both hot and cold month was $6.67 \%$ and $3.19 \%$ respectively; also it noticed that the percent of infection with mange in both male and female camel was $4.97 \%$ and $4.21 \%$ respectively, from another side the highest percent of infection with mange was $7.4 \%$ at camels between the of 7-8 years (Hamed 2005). Haematological disorders in infected animals involved microcytic hypochromic anemia and leukocytosis (Egbe-Nwiyi et al., 1996).

\section{MATERIALS and METHODS}

\section{Animals}

157 Camelus dromedarius from three different areas (Draw, Gharb Aswan Village and Gharb Sohil Village) in Aswan Governorates were examined from April 2014 to April 2015 in this study, 11 camels suffered from blood parasite Trypanosoma evansi, 31 camels suffered from blood and internal parasites Tricuries Cameli, 99 camels suffered from clinical mange infestation, free from internal and blood parasites and 16 clinically healthy camels.

Animals were clinically inspected during the period from April 2014 to April 2015 and only 105 camels 
infested with mange were used for hematological and biochemical analysis included 92 males and 13 females.

Sixteen healthy camels were clinically normal and free from external, internal and blood parasites used as a control group.

Infected camel was naturally diseased with Sarcoptic mite showed symptoms of itching, purities, erythema, corrugation of the skin and alopecia.

\section{Samples}

Blood samples

Blood samples were used in the same day for hematological examination and blood smear. The blood was allowed to flow from jugular vein puncture, with clean, dry sterile needle into dry clean sterile vials containing anticoagulant EDTA (ethylene diamin tetra acetic acid) in a concentration of $1 \mathrm{mg} /$ $1 \mathrm{ml}$ blood. Another sample was taken in a dry, clean and sterile centrifuge tubes without anticoagulant. These samples were allowed to clot at room temperature, the clotted blood were centrifugated at $5000 \mathrm{rpm}$ for 20 minutes to obtained clear, non haemolized sera and stored at $-20^{\circ} \mathrm{C}$ until used.

\section{Skin samples}

Skin samples were taken from slaughtered camels naturally infected with sarcoptic mange from different parts of camel for histopathological examination. These were fixed in $10 \%$ neutral formalin till examination.

\section{Fecal samples}

Rectal fecal samples were collected individually in clean plastic covered cups for the detection of the gastrointestinal parasites.

\section{Methods}

Haematological examination

Total erythorocytes count (TEC), total leukocytes count (TLC) were done according to (Feldman et al., 2000), and hemoglobin ( $\mathrm{Hb}$ ) was done automatically using Drab kin's Solution by colorimetric method using the biochemical analysizer model AE-600N. For the differential leukocyte count, three blood smears were taken from each blood sample and stained with Geimsa (Bancroft et al., 1996).

\section{Biochemical examination}

All biochemical analysis was carried out using the test kits obtained commercially and the results were read at appropriate wavelength using the biochemical analysizer model AE-600N.

The concentrations of serum total protein, glucose, Zinc, Copper, Bilirubin, Cholesterol, Magnesium and albumin were determined spectrophotometerically according to (Tietz 1994), Calcium and HDL levels concentration were estimated according to (Young 1995), AST and ALT levels in blood sera according to (Reitman et al., 1957) and Triglycerides (Bucolo and Divad 1973). Kits obtained from Biodiagnostic Co., Giza, Egypt and HEMOBIO Co., Cairo.

Globulin concentration was calculated by subtracting the obtained value of albumin from the total proteins. It was expressed in g/dl. Also, Albumin/Globulin $(\mathrm{A} / \mathrm{G})$ ratio was obtained by dividing value of albumin on globulin.

\section{Fecal samples}

Fecal samples were examined by the concentration flotation technique using saturated salt solution according to (Coles 1986).

\section{Histopathological examination}

Skin Specimens from different parts of slaughtered camel were taken from the infected mangy areas for studying histopathological changes. These materials were fixed immediately in $10 \%$ formal saline, dehydrated, cleared, embedded in paraffin, sectioned at $4 \mu \mathrm{m}$ and stained with Hematoxylin and Eosin (Carleton et al., 1967).

\section{Statistical Analysis}

The result was evaluated using Analysis of variance (ANOVA) and Duncan using Statistical Package for Social Science (SPSS) computer programs (2002).

\section{RESULTS}

Examination of camels by blood smear and fecal analysis show, eleven camels suffered from blood parasite Trypanosoma evansi, thirty one camels suffered from internal parasite Tricuries Cameli, these animals were excluded from the hematological and biochemical analysis.

\section{Hematological parameters}

Total erythrocyte count (TEC) and hemoglobin ( $\mathrm{Hb})$ concentrations were decreased significantly in the infected camel compare to apparently healthy. Total leukocyte count (TLC), Neutrophils and Eosinophils were increased significantly in infected camel compare to the healthy, while Monocytes and Lymphocytes were decreased significantly in the infected camel, in addition to there no significant changes in the Basophils (Table 1).

\section{Biochemical parameters}

Biochemical parameters show no significantly different in Albumin, ALT, HDL and Calcium levels between healthy and infected camel. There was a significant increased in Cholesterol, AST and LDL concentrations in infected animals than healthy, while it show a significant decreased in Total protein, globulin, bilirubin, Znic, Copper and Magnesium. Triglyceride and glucose concentrations increased in 
male infected camel significantly than healthy, while it shows significantly decreased in female animals (Table 2).

Histopathological examination

Sever hyperplasia of epidermis with hyper keratosis and degeneration, hyalinization in prickle cell layers (hyalinized focally), with inflammatory cells infiltration and hyperkeratosis forming homogenous eosinophilic structure with mononuclear inflammatory cells infiltration (Figure 1.).

Table 1: Hematological parameters in Healthy and mange infected camel

\begin{tabular}{|c|c|c|c|c|}
\hline \multirow[b]{2}{*}{$\begin{array}{c}\text { Parameters } \\
\text { NO. }\end{array}$} & \multicolumn{2}{|c|}{ Healthy } & \multicolumn{2}{|c|}{ Mange infected } \\
\hline & $\begin{array}{c}\text { Males } \\
12 \\
\end{array}$ & $\begin{array}{c}\text { Females } \\
4 \\
\end{array}$ & $\begin{array}{c}\text { Males } \\
80 \\
\end{array}$ & $\begin{array}{c}\text { Females } \\
9 \\
\end{array}$ \\
\hline TEC & $5.9 \pm 1.26^{a}$ & $3.83 \pm 0.1^{b}$ & $4.28 \pm 0.98$ & $3.22 \pm 0.15^{\mathrm{c}^{*}}$ \\
\hline TLC & $7.42 \pm 2.04^{b}$ & $7.68 \pm 0.15^{b}$ & $10.23 \pm 4.08^{a}$ & $11.65 \pm 1.29^{a^{*}}$ \\
\hline Hemoglobin (g/dl) & $10.95 \pm 1.01^{b}$ & $12.55 \pm 0.13^{a}$ & $10.38 \pm 0.57^{b}$ & $10.7 \pm 0.28^{b^{*}}$ \\
\hline Neutrophils \% & $52.33 \pm 9.48^{b}$ & $57.0 \pm 0.82^{a}$ & $57.9 \pm 10.73^{b}$ & $62.81 \pm 2.17^{a^{* * *}}$ \\
\hline Basophils \% & $0.18 \pm 0.08$ & $0.25 \pm 0.06$ & $\mathbf{0 . 1 6} \pm \mathbf{0 . 0 7}$ & $0.14 \pm 0.05^{N S}$ \\
\hline Eosinophils \% & $8.33 \pm 2.5^{a b}$ & $6.50 \pm 0.58^{b}$ & $11.14 \pm 4.03^{a}$ & $12.18 \pm 3.71^{a^{*}}$ \\
\hline Lymphocytes \% & $35.5 \pm 5.58^{b}$ & $36.0 \pm 0.82^{a}$ & $29.46 \pm 4.17^{b}$ & $23.18 \pm 2.99^{b} * *$ \\
\hline Monocytes \% & $1.67 \pm 0.05^{a}$ & $1.15 \pm 0.06^{a}$ & $1.1 \pm 0.09^{b}$ & $1.05 \pm 0.07^{b^{*}}$ \\
\hline
\end{tabular}

All data expressed as Mean \pm SD.

* Significant differences at $\mathrm{P}<0.05$

** Significant differences at $\mathrm{P}<0.001$

The different letters after mean $(a, b$ and $c)$ indicated significance but same letters indicated no significance

Table 2: Biochemical parameters in Healthy and mange infected camel

\begin{tabular}{|c|c|c|c|c|}
\hline \multirow[b]{2}{*}{$\begin{array}{c}\text { Parameters } \\
\text { NO. }\end{array}$} & \multirow[b]{2}{*}{$\begin{array}{c}\text { Males } \\
12\end{array}$} & \multirow{2}{*}{$\begin{array}{c}\text { Healthy } \\
\text { Females } \\
4\end{array}$} & \multicolumn{2}{|c|}{ Mange infected } \\
\hline & & & $\begin{array}{c}\text { Males } \\
\mathbf{8 0} \\
\end{array}$ & $\begin{array}{c}\text { Females } \\
9 \\
\end{array}$ \\
\hline Total protein (g/dl) & $7.75 \pm 2.06^{a}$ & $6.4 \pm 0.92^{b}$ & $6.4 \pm 0.92^{b}$ & $4.57 \pm 0.55^{c * *}$ \\
\hline Albumin (g/dl) & $2.94 \pm 0.49$ & $2.93 \pm 0.15$ & $2.75 \pm 0.54$ & $2.46 \pm 0.67^{\mathrm{NS}}$ \\
\hline Globulin (g/dl) & $4.81 \pm 1.99^{a}$ & $3.48 \pm 0.83^{b}$ & $1.89 \pm 0.95^{c}$ & $2.11 \pm 0.57^{c_{* *}}$ \\
\hline A/G ratio & $0.72 \pm 0.34^{b}$ & $1.89 \pm 1.17^{a}$ & $0.87 \pm 0.18^{a b}$ & $1.33 \pm 0.82^{a b *}$ \\
\hline Glucose (mg/dl) & $54.92 \pm 8.56^{b}$ & $86.75 \pm 12.28^{a}$ & $77.14 \pm 21.94^{a}$ & $72 \pm 12.84^{\mathrm{ab} *}$ \\
\hline ALT (GPT)(U/L) & $30.17 \pm 10.4$ & $32.25 \pm 10.4$ & $35.7 \pm 13.39$ & $41.1 \pm 7.15^{\mathrm{NS}}$ \\
\hline AST (GOT)(U/L) & $26.6 \pm 15.4^{b}$ & $35.5 \pm 8.39^{a b}$ & $37.2 \pm 10.2^{\mathrm{ab}}$ & $53.68 \pm 10.1^{a_{* *}}$ \\
\hline LDL (mg/dl) & $26.74 \pm 20.53^{b}$ & $49.03 \pm 2.6^{a b}$ & $66.97 \pm 38.7^{a}$ & $73.11 \pm 8.33^{a *}$ \\
\hline HDL (mg/dl) & $23.75 \pm 10.56$ & $12.8 \pm 1.75$ & $21.9 \pm 24.56$ & $12.56 \pm 2.13^{\mathrm{NS}}$ \\
\hline Triglycerides & $39.08 \pm 33.16^{b}$ & $147 \pm 17.72^{a}$ & $114.8 \pm 45.18^{a}$ & $133 \pm 12.81^{\mathrm{a} * *}$ \\
\hline Cholesterol (mg/dl) & $64.67 \pm 18.5^{c}$ & $73.03 \pm 47.96^{b c}$ & $99.29 \pm 32.86^{a}$ & $119.78 \pm 7.63^{a_{* *}}$ \\
\hline Bilirubin (mg/dl) & $5.08 \pm 1.38^{a}$ & $0.85 \pm 0.06^{b}$ & $2.0 \pm 1.9^{b}$ & $0.74 \pm 0.14^{b * *}$ \\
\hline Zinc(mg/dl) & $3.41 \pm 0.4^{a}$ & $3.65 \pm 0.13^{a}$ & $1.8 \pm 0.4^{b}$ & $1.46 \pm 0.27^{b * *}$ \\
\hline Copper (mg/dl) & $6.81 \pm 0.4^{\mathrm{a}}$ & $5.53 \pm 0.39^{b}$ & $4.84 \pm 0.47^{c}$ & $4.80 \pm 0.07^{c^{* *}}$ \\
\hline Magnesium(mg/dl) & $2.74 \pm 0.14^{a}$ & $2.6 \pm 0.14^{a b}$ & $1.75 \pm 0.59^{c}$ & $2.16 \pm 0.21^{b c * *}$ \\
\hline Calcium(mg/dl) & $10.63 \pm 2.03$ & $9.08 \pm 0.13$ & $10.02 \pm 2.46$ & $8.82 \pm 0.9^{N S}$ \\
\hline
\end{tabular}

All data expressed as Mean \pm SD.

* Significant differences at $\mathrm{P}<0.05$

** Significant differences at $\mathrm{P}<0.001$

The different letters after mean $(\mathrm{a}, \mathrm{b}$ and $\mathrm{c}$ ) indicated significance but same letters indicated no significance 

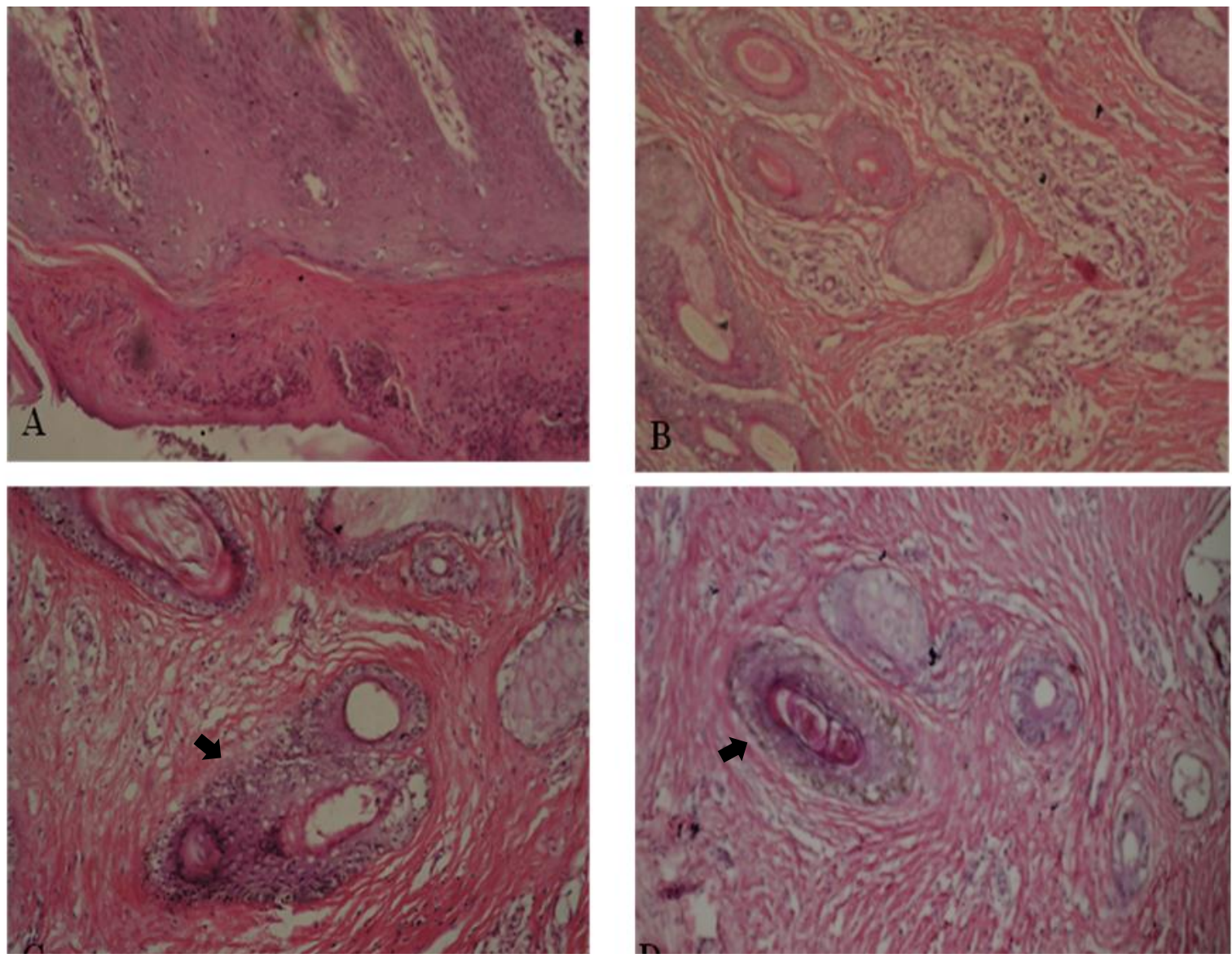

Fig. 1: A and B. Sever focal epidermal hyperplasia, hyperkeratosis and hyalinization with inflammatory cells infiltration $\mathrm{H} \& \mathrm{E} \times 10$.

$\mathrm{C}$ and D. Mites are shown in dermis and epidermis with infiltration of dermis with mononuclear inflammatory cells infiltration and eosinophilia (arrows) H\&E $\times 40$.

\section{DISCUSSION}

According to the difference in blood and biochemical parameters in animals infected with mange than healthy animals, that is an indication for the serious problems in camel caused by mange, which had a negative reflected on animals health and production, specially camel work under very hard climate, that lead to loss in economic importance of camel as animals for hard climate. This difference may be due to the allergic reaction caused by mites or their products of inflammatory reactions and may be due to activation of immune system by the parasite.

We cannot deny that parasite shares the available nutrients in the plasma pool with animals themselves, and may be infections with sarcoptic mange responsible for compromised very change in hepatic function. (Mottelib 1993), (Egbe-Nwiyi et al., 1996), (Sayed 1998), (Mahran et al., 2004), (Parmar et al., 2005), (Manisha et al., 2005) and (Sena et al., 1999). In addition to the difference between female and male in some parameters may be due to the differences in hormones between the female and male that can be reflect on blood and biochemical parameters, in this filed we need more study for evaluation of infection mange in camel and the ways for treatment should be in focus in the next study.

\section{REFERENCE}

Al-Saad, K.; L-Khafaji, N.J. and AL-Sadi, H.I. (2000): Studies of an outbreak of sarcoptic mange in camel. Iraqi journal of veterinary sciences. Vol. 13 No.1pp. 147-155.

Bancroft, J.D. and Stevens, A. (1996): The haematoxylin and eosin. Theory and practice of histological techniques. $4^{\text {th }}$, Ed. pp. 99-112.

Bucolo, G. and David, H. (1973): Quantitative determination of serum triglycerides by the use of enzyme. Clin. Chem. pp. 476-482.

Carleton, H.M.; Druy, R.A.B. and Willington, E.A. (1967): Carleton's Histological Technique $4^{\text {th }}$ Ed. Oxford Univ. Press, N.Y.

Coles, E.H. (1986): Veterinary clinical pathology. $2{ }^{\text {nd }}$ Ed. Sanunders company. Philadelphia and London.

Egbe-Nwiyi, T.N. and Chaudhari, S.R. (1996): Sarcoptosis in camels of Nigeria: prevalence, 
associated haematological and histopathological changes. Pakistan Veterinary Journal. 16(2):65-67.

Feldman, B.F.; Zinkl, J.G. and Jain, N.C. (2000): Schalm's Veterinary Hematology. Lippincott Williams and Wilkins. USA.

Hamed, M. (2005): Epidemiological studies on infectious skin affections of camels (camelus dermedarius) in Upper Egypt 2005. Assuit University.

Higgin, S. (1985): Common ectoparasites of the camel and their control. Br. Vet. J. 141: 197.

Kamal, A. (2008): Some Biochemical, Haematological and clinical studies selected Ruminal and Blood Constituent in Camel affected by various diseases. Research Journal of Veterinary Science.

Mahran, O.M. and Saleh, M.A. (2004): Prevalence of ectoparasites and their effect on some biochemical indices in camels (Camelus dromedarius) at Shalatin City. Assiut Veterinary Medical Journal. 50(100): 164-187.

Manisha Mathur, Hemant Dadhich, Sharma, G.D. and Sandeep Khare. (2005): A study of haemato-biochemical changes in camels affected with cutaneous ectoparasitoses in Rajasthan. Veterinary Practitioner. 6(2): 131132.

Mottelib, A.A. (1993): The efficacy of ivermectin in treatment of mange in camels in Al-Qassim, Saudi Arabia. Proceedings of the Second Scientific Congress Egyptian Society for Cattle
Diseases, 5-7 December 1993 Assiut - Egypt. (2): 305-313.

Parmar, A.J.; Veer Singh, Chaudhary S.S.; Prajapati, B.H. and Sengar, Y.S. (2005): Haematobiochemical studies on sarcoptic mange in camel (Camelus dromedarius) in Banaskantha district (North Gujarat). Journal of Parasitic Diseases. 29(1): 71-73.

Reitman, S. and Frankel, S.A. (1957): Colorimetric method for the determination of serum oxaloacetic and glutamic pyruvate transaminase. Am. J. clin. Pathol. 28: 56-63.

Sayed, A.S. (1998): Clinical, Haematological and some Trace Elements status in Healthy and Emaciated Camels.

Sena, D.S.; Mal, G.; Kumar, R.; Singh, M.N.; Chirania, B.L. and Sahani, M.S. (1999): Clinico-haematological and therapeutic studies on mange in camel. Indian vet. Journal. 76:998-1000. In Assiut and New Valley. Assiut Vet. Med. J. Vol. 39 No. 77.

SPSS, 11. (2002): Statistical Package for Social Science, SPSS for windows Release 11.0.0, "Standard Version, copyright SPSS Inc., 19892002.

Tietz, N.W. (1994): Textbook of clinical chemistry 2nd ed. Burtis C.A. Ashwood E.R. (ed.) Saunders co., London, UK.

Young, D.S. (1995): Effects of drugs on Clinical Lab. Tests, 4th ed AACC Press, 1995.

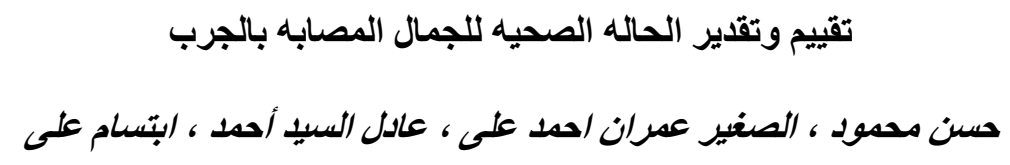

Email: hayvet2002@yahoo.com

Assiut University web-site: www.aun.edu.eg

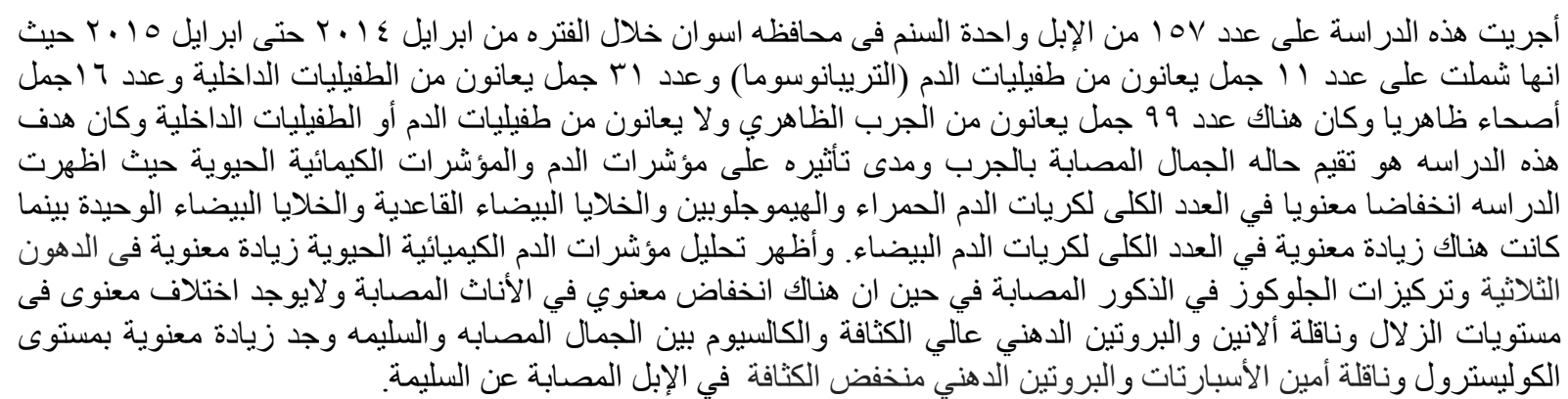

